\title{
DNA evidence of Trypanosoma cruzi in the Chilean wild vector Mepraia spinolai (Hemiptera: Reduviidae)
}

\section{Carezza Botto-Mahan ${ }^{+}$, Sylvia O rtiz*, Marlene Rozas* , Pedro E Cattan**, Aldo Solari*}

\author{
Departamento de Ciencias Ecológicas, Facultad de Ciencias *Programa de Biología Celular y Molecular, Facultad de Medicina \\ **Departamento de Ciencias Biológicas Animales, Facultad de Ciencias Veterinarias y Pecuarias Universidad de Chile, \\ Santiago, Chile
}

\begin{abstract}
Molecular evidence showed 46.2\% of Trypanosoma cruzi infection in Mepraia spinolai insects from North-Central Chile, which is significantly higher than previous reports of up to $26 \%$ by microscopic observation. Our results show similar infection levels among nymphal stages, ranging from 38.3 to $54.1 \%$, indicating that younger nymphs could be as important as older ones in parasite transmission. A cautionary note must be stressed to indicate the potential role of $\mathrm{M}$. spinolai in transmitting $\mathrm{T}$. cruzi in country areas due to the high infection level detected by molecular analysis.
\end{abstract}

Key words: Triatominae - Chagas disease - Kissingbug

Chagas disease is a serious human parasitic disease in America that is caused by the flagellate protozoan Trypanosoma cruzi, and transmitted by blood-sucking insects of the subfamily Triatominae (Hemiptera: Reduviidae) (Panzera et al. 2004). Detection of T. cruzi can be carried out through different methodologies such as direct microscopic observation, hemoculture, xenodiagnosis, and in the last decade the polymerase chain reaction (PCR). It is well known that PCR-based detection from feces or urine of reduviid bugs, and blood samples from mammals is more efficient than the other techniques (Moser et al. 1989, Breniere et al. 1992, Russomando et al. 1992, 1996). However, scarce information has been reported about infection levels of wild triatomine populations using molecular techniques.

Mepraia spinolai is one of the two triatomine species responsible of $T$. cruzi transmission in arid and semiarid Chile (Lent et al. 1994). This strictly hematophagous and diurnal species distributes between $18^{\circ}$ and $34^{\circ} \mathrm{S}$, and its main habitat includes stay grounds, bird nests, rock crevices, and caves although it has been also found in rustic and abandoned houses (Lent \& Wygodzinsky 1979, Schofield et al. 1982, Canals et al. 1997). Even though, human blood index for $M$. spinolai indicates that this species is not an important vector of $T$. cruzi, the insect reaches high population densities in quarries near human dwellings suggesting an increasing risk of Chagas disease transmission in these zones (Cattan et al. 2002). Studies using microscopic methods have reported high variability in $T$.

Financial support: Fondecyt 2010022, 3050033, 1040762, 1040711\& IAEA CHI 11767

+Corresponding author. E-mail: cbotto@uchile.cl

Received 15 December 2004

Accepted 15 April 2005 cruzi infection levels of wild insect populations, ranging 0-26\%, depending on the locality (Apt \& Reyes 1986, Frias et al. 1995, Ordenes et al. 1996, Canals et al. 2001). In this paper we document the level of T. cruzi infection in a wild population of $M$. spinolai using PCR and direct microscopic techniques.

Individuals of $M$. spinolai were collected from April to August 2002 at Las Chinchillas National Reserve ( $\left.31^{\circ} 30^{\prime} \mathrm{S}, 71^{\circ} 06^{\prime} \mathrm{W}\right)$, located approximately $300 \mathrm{~km}$ north from Santiago (Chile). In this area, the climate corresponds to a semiarid Mediterranean type with most rainfall concentrated in the winter season (di Castri \& Hajek 1976). First to fifth instar nymphs were collected from the same ecotope, characterized by stony slopes with low to moderate human activity and traffic of cattle yard animals. In the collecting site, $M$. spinolai individuals feed on free ranging introduced rabbits (Oryctolagus cuniculus), and small native mammals (Phyllotis darwini, Octodon degus, Abrothrix olivaceus, Oligoryzomys longicaudatus, and Thylamys elegans) inhabiting the area (Rengifo 2000). Captured nymphs were kept separately inside a climate chamber at $27^{\circ} \mathrm{C}, 70 \% \mathrm{RH}$ and $14: 10 \mathrm{~h} \mathrm{~L}: \mathrm{D}$ cycle.

The intestinal content of $182 \mathrm{M}$. spinolai individuals were removed through abdominal extrusion, and inspected by light microscopy (Nikon Diaphot-FXA) for the presence of T. cruzi (Schenone et al. 1980). For microscopic observation, $5 \mu \mathrm{l}$ of fresh intestinal content was compressed between a slide and an $18 \times 18 \mathrm{~mm}$ cover slip. The presence of motile parasites in 50 microscopic fields was registered using $\times 400$ magnification. The remaining intestinal sample was mixed with $200 \mu \mathrm{l}$ of PBS buffer, centrifuged at $10,000 \mathrm{xg}$, and frozen at $-20^{\circ} \mathrm{C}$ for PCR assay. Most wild insects were naturally fasted implying that intestinal contents were free of fresh blood. Therefore, intestinal samples did not require DNA extractions as previously described for other insect vectors (Russomando et al. 1996). The amplification reactions were performed with oligonucleotides 121 and 122, which anneal to the four 
constant regions present in the minicircles of $T$. cruzi (Wincker et al. 1994). This PCR test is directed to minicircle DNA that is present in more than 10,000 copies per parasite, therefore, the assay is highly sensitive and appropriate for diagnosis. The intestinal sample was boiled for 10 min, centrifuged at $10,000 \times \mathrm{g}$, and $5 \mu 1$ of the supernatant was used as DNA template. Each experiment included a negative control where the DNA sample was changed by $\mathrm{H}_{2} \mathrm{O}$, and a positive control with a purified DNA of $T$. cruzi. PCR products of $330 \mathrm{bp}$ were analyzed by electrophoresis in a $2 \%$ agarose gel and visualized by ethidium bromide staining. For each sample, PCR assay was performed thrice. As confirmatory assay, amplified DNAs were transferred to nylon membranes, denatured, crosslinked with UV irradiation, hybridized using a total kinetoplast DNA from T. cruzi as a universal probe, and labeled by a random priming method with $\left[\mathrm{a}^{32} \mathrm{P}\right] \mathrm{dCTP}$ (Solari et al. 1991).

Direct microscopic observation indicated that 9.89\% of the nymphs were infected with T. cruzi. Molecular results showed $100 \%$ correspondence between the ethidium bromide and the autoradiography intensity bands (Southern analysis). PCR assays indicated that $46.15 \%$ of the nymphs were infected with $T$. cruzi, indicating as expected that previous microscopic observations as well as the ones reported here provide underestimated infection levels (Schenone et al. 1980, Ordenes et al. 1996). Interestingly, PCR assays revealed a similar level of infection among the different nymphal stages, ranging 38.3-54.1\% (Table). Microscopic observation does not only underestimate the level of infection of this wild triatomine but also the importance of younger nymphs in parasite transmission.

\section{TABLE}

Molecular and microscopic evidence of Trypanosoma cruzi infection in the wild vector Mepraia spinolai

\begin{tabular}{lccc}
\hline $\begin{array}{l}\text { Nymphal } \\
\text { stage }\end{array}$ & $\begin{array}{c}\text { PCR } \\
(\%)\end{array}$ & $\begin{array}{c}\text { Microscopy } \\
(\%)\end{array}$ & $\begin{array}{c}\text { Sample size } \\
(\mathrm{N})\end{array}$ \\
\hline I-II & 48.21 & 3.57 & 56 \\
III & 45.24 & 11.91 & 42 \\
IV & 38.30 & 10.64 & 47 \\
V & 54.05 & 16.22 & 37 \\
\hline
\end{tabular}

PCR: polymerase chain reaction

Assessment of T. cruzi infection levels in wild vectors may have important consequences for the disease control. Relatively low infection levels in M. spinolai have been described in different endemic areas of Chile (Schenone et al. 1980, Ordenes et al. 1996), and therefore, almost no attention has been paid on this wild species. Even though the main vector of $T$. cruzi in Chile (Triatoma infestans) has been virtually eliminated, the potential importance of M. spinolai in transmitting T. cruzi cannot be overlooked. Consistent PCR measurements of infection levels in the wild vector and mammal populations are needed for disease epidemiology assessments in the wild cycle of $T$. cruzi.

\section{ACKNOWLEDGMENTS}

Rodrigo Medel and Mauricio Canals made important suggestions that improved the clarity of this manuscript.

\section{REFERENCES}

Apt W, Reyes H 1986. Aspectos epidemiológicos de la enfermedad de Chagas en Chile I. Distribución geográfica, índices de infección en vectores y en humanos. Parasitol al Día 10: 94-101.

Breniere SF, Bosseno MF, Revollo S, Rivera MT, Carlier Y, Tibayrenc M 1992. Direct identification of Trypanosoma cruzi natural clones in vectors and mammalian hosts by polymerase chain reaction amplification. Am J Trop Med Hyg 46: 335-341.

Canals M, Cruzat L, Molina MC, Ferreira A, Cattan PE 2001. Blood host sources of Mepraia spinolai (Heteroptera: Reduvidae), wild vector of Chagas disease in Chile. J Med Entomol 38: 303-307.

Canals M, Solis R, Valderas J, Ehrenfeld M, Cattan PE 1997. Preliminary studies on temperature selection and activity cycles Triatoma infestans and T. spinolai (Heteroptera: Reduviidae) Chilean vectors of Chagas disease. J Med Entomol 34: 11-17.

Cattan PE, Pinochet A, Botto-Mahan C, Acuña MI, Canals M 2002. Abundance of Mepraia spinolai in a periurban Zone of Chile. Mem Inst Oswaldo Cruz 97: 285-287.

di Castri F, Hajek ER 1976. Bioclimatología de Chile, Ediciones de la Universidad Católica de Chile, Chile, 159 pp.

Frias D, Solari A, González C, Henry A, Alviña A 1995. Indices de infección de Mepraia spinolai con Trypanosoma cruzi, su invasión a ambientes domésticos e interacción con Triatoma infestans. Parasitol al Día 19: 195.

Lent H, Wygodzinsky P 1979. Revision of the triatominae (Hemiptera: Reduviidae) and their significance as vectors of Chagas disease. Bull Am Mus Nat Hist 163: 130-138.

Lent H, Jurberg J, Galvão C 1994. Revalidação de gênero Mepraia Mazza, Gajardo and Jorg, 1940 (Hemiptera, Reduviidae, Triatominae). Mem Inst Oswaldo Cruz 89: 347-352.

Moser DR, Kirchhoff LV, Donelson JE 1989. Detection of Trypanosoma cruzi by DNA amplification using the polymerase chain reaction. J Clin Microbiol 27: 1477-1482.

Ordenes HV, Ehrenfeld M, Cattan P, Canals M 1996. Infección Tripanotriatomino de Triatoma spinolai en una zona de riesgo epidemiológico. Rev Med Chile 124: 1053-1057.

Panzera F, Dujardin JP, Nicolini P, Caraccio MN, Rose V, Tellez T, Bermúdez H, Bargues MD, Mas-Coma S, O’Connor JE, Pérez R 2004. Genomic changes of Chagas disease vector, South America. Emerg Infect Dis 10: 438-446.

Rengifo A 2000. Preferencias Alimentarias Específicas de Mepraia spinolai por Vertebrados Frecuentes en su Hábitat, Undergraduate Thesis, Universidad de Chile, Santiago, $69 \mathrm{pp}$.

Russomando G, Figueredo A, Almirón M, Sakamoto M, Morita K 1992. Polymerase chain reaction-based detection of Trypanosoma cruzi DNA in serum. J Clin Microbiol 30: 286288.

Russomando G, Rojas de Arias A, Almiron M, Figueredo A, 
Ferreira ME, Morita M 1996. Trypanosoma cruzi: polymerase chain reaction-based detection in dried feces of Triatoma infestans. Exp Parasitol 83: 62-66.

Schenone H, Villarroel F, Rojas A, Alfaro E 1980. Factores biológicos y ecológicos en la epidemiología de la enfermedad de Chagas en Chile. Bol Chil Parasitol 40: 42-54.

Schofield CJ, Apt W, Miles MA 1982. Ecology of Chagas disease in Chile. Ecol Dis 1: 117-129.
Solari A, Venegas J, González E, Vasquez C 1991. Detection and classification of Trypanosoma cruzi by DNA hybridization with non radioactive probes. J Protozool 38: 559565.

Wincker P, Britto C, Pereira JB, Cardoso MA, Oeleman O, Morel CM 1994. Use of a simplified polymerase chain reaction procedure to detect Trypanosoma cruzi in blood samples from chronic chagasic patients in a rural endemic area. Am J Trop Med Hyg 51: 771-777. 
